\begin{tabular}{l|c|c}
\hline ISSN: 0001-5113 & ACTA ADRIAT., & ORIGINAL SCIENTIFIC PAPER \\
AADRAY & $58(1): 117-125,2017$ & \\
\hline
\end{tabular}

\title{
Reproductive patterns of bogue, Boops boops (Sparidae), in the southeastern Adriatic Sea
}

\author{
Tatjana DOBROSLAVIĆ*, Renata MOZARA, Branko GLAMUZINA and Vlasta BARTULOVIĆ \\ University of Dubrovnik, Department of Aquaculture, Ćira Carića 4, Croatia \\ *Corresponding author, e-mail: tatjana.dobroslavic@unidu.hr
}

The reproductive characteristics of bogue (Boops boops) in the southeastern Adriatic Sea are presented in this study. The analysis is based on 676 specimens caught by seine net from December 2011 to November 2012. Total length of females ranged from 13.3 to $29.3 \mathrm{~cm}$ and males from 15.1 to $26.3 \mathrm{~cm}$. The overall sex ratio of females to males was 1:0.85 $\left(\chi^{2}=4.314 ; P<0.05\right)$ with a slightly higher number of females in the largest size class. Length-weight relationship for the total population indicated negative allometric growth $(b=2.911)$. Values of the condition factor are relatively low for both sexes. Maximum values were recorded in September 1.025 for females and 1.029 for males. Gonadosomatic index and histological examination showed that the spawning season of the bogue in the Adriatic is from January to May with peak in February. Six stages of gonad development were identified: immature, undergoing maturation, ripening, ripe, spawning and spent. The monthly distribution of the different sexual maturity stages and the frequency distribution of oocyte diameter revealed that this species is a batch spawner.

Key words: length-weight relationship, oogenesis, spermatogenesis, reproduction, Boops boops

\section{INTRODUCTION}

The bogue, Boops boops (Linnaeus, 1758) is one of the most abundant species of the family Sparidae (NELSON, 2006). It mainly inhabits Mediterranean Sea and eastern Atlantic (JARDAS, 1996). It is the only Sparidae species included in the top 13 most landed demersal fish species in the Mediterranean Sea, despite its low commercial value (LLEONART \& MAYNOU, 2003).

The bogue is a medium sized, up to 36.0 $\mathrm{cm}$ total length, more common between 10.0 and $20.0 \mathrm{~cm}$, demersal and semipelagic species (JARDAS, 1996). It can be found as deep as 350 $\mathrm{m}$ over a variety of substrates including mud, sand, rocks and seaweeds, though it is more abundant at depths of $100 \mathrm{~m}$ and less (JARDAS,
1996; RELINI et al., 1999). Females of bogue reach sexual maturity at length of $12 \mathrm{~cm}$ and males at 13 cm (JARDAS, 1996; EL-AGAMY et al., 2004). Hermaphroditic behaviour has been reported in this species in the basic form of protoginy. Males may develop directly from the juvenile state or may develop from adult females by sex change (GORDO, 1995).

Despite the fact that it is commercially important species in the Adriatic Sea only some aspects such as, length-weight relationship (DULČIĆ \& GLAMUZINA, 2006) and juveniles diet (DOBROSLAVIĆ et al., 2012) have been investigated. Reproductive biology of this species was studied in the Aegean Sea (SOYKAN et al., 2015), Tyrrhenian Sea (BOTTARI et al., 2014), Egyptian coast of Mediterranean (EL-AGAMY et al., 2004) 
and on the Portuguese coast (GORDO, 1995; MONTEIRO et al., 2006).

The aim of this study was to describe reproductive characteristics of bogue in the Adriatic Sea, based on histological analysis of gonad development. Due to the fact that all aspects of reproductive biology have an important role for assessment and management plans as well as understanding annual changes in the population, data obtain in this study can be used for future stock management of this species.

\section{MATERIAL AND METHODS}

Adult specimens were collected monthly from December 2011 to November 2012 in the southern Adriatic Sea $\left(42.75^{\circ} \mathrm{N} ; 17.83^{\circ} \mathrm{E}\right)$ using seine net. A total of 676 individuals were examined in this study period. For each fish, total length (TL) was measured to the nearest $0.1 \mathrm{~cm}$ and weighed $(W)$ to the nearest $0.1 \mathrm{~g}$. Fish was gutted, and gonads were removed and weight $( \pm 0.001)$ measured. The length-weight relationship was determined by linear regression analysis and scatter diagrams of length and weight were plotted. It was calculated using equation $W=a L^{b}$; where $a$ is the regression intercept and $b$ is the regression slope, $W$ is the wet weight (g) and $L$ is the total length (cm) (FROESE, 2006). Fulton's condition factor was calculated following FROESE (2006): $K=\left(W / L^{3}\right) \times 100$.

Spawning period was established with monthly variations of the gonadosomatic index (GSI) calculated as: $\mathrm{GSI}=\left(W_{\mathrm{g}} /\left(W-W_{\mathrm{g}}\right)\right) \times 100$, where $W \mathrm{~g}$ is gonad and $W \mathrm{t}$ total body weight. For histological analysis gonad tissue of 120 females and 120 males was fixed in $8 \%$ buffered formalin. Fixation was followed by dehydration in increasingly concentrated ethanol, tissue clearing and embedding in paraffin. Tissue was then sectioned on microtome $(5 \mu \mathrm{m})$ and stained by hematoxylin and eosine dye. After the standard tissue processing histological slides were used for defining the gonads development stages. It was classified following the classification proposed by MURUA \& MOTOS (2006) as: immature, undergoing maturation, ripening, ripe, spawning or spent. Stages of oocyte development were classifies as: oocytes in primary growth (early and advanced), cortical alveoli stage, vitellogenesis (early and advanced), migratory nucleus stage, hydrated oocytes and postovulatory follicles (HUNTER et al., 1986; TYLER \& SUMPTERN, 1996). Male germ cells were classified as: spermatogonia, spermatocysts, spermatids and spermatozoa (GRIER, 1981).

Gravimetric method was used to estimate total fecundity. For each female $(n=60)$ after weighing the ovaries, three (F1, F2, F3) subsamples $(0,001 \mathrm{~g})$ were taken from anterior, central and posterior ovary lobe. The number of eggs in each subsample was estimated using the following equation: Fecundity $=$ Number of eggs in subsample x Ovary weight / Weight of subsample. The individual fecundity for each female was calculated by following equation Fecundity $=\mathrm{F} 1+\mathrm{F} 2+\mathrm{F} 3 / 3$ (LAEVASTU, 1965, YELDEN \& AVSAR, 2000).

\section{RESULTS AND DISCUSSION}

Out of 676 individuals, $365(50.7 \%)$ were females and $311(43.2 \%)$ males. Total length of females ranged from 13.3 to $29.3 \mathrm{~cm}$ with a mean value of $18.41 \pm 2.0 \mathrm{~cm}$ and males from 15.1 to $26.3 \mathrm{~cm}(18.29 \pm 1.72 \mathrm{~cm})$ (Fig. 1) with no statistically significant difference between females and males (Mann-Whitney $U=54493$, $P>0,05)$. The overall sex ratio of females to males was 1:0.85 $\left(\chi^{2}=4.314 ; P<0.05\right)$.

Length-weight relationship shows negative allometric growth for females $\left(W=0.0131 L_{t}^{2.884}\right.$,

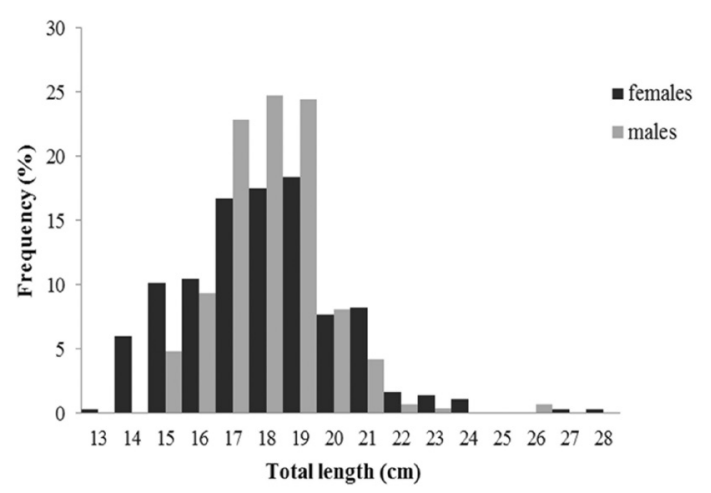

Fig.1. Length frequency distribution of male $(n=311)$ and female $(n=365)$ bogue, Boops boops in the Adriatic Sea 
Table 1. Comparison of the values of weight-length relationships for Boops boops obtained in this study with other studies carried out in the Adriatic Sea, Portugal coast, SW Spain, Tyrrhenian and Aegean Sea (LR - length range; GT - growth type)

\begin{tabular}{|l|l|c|c|c|c|c|c|}
\hline Authors & Location & $\boldsymbol{n}$ & LR (cm) & $\boldsymbol{a}$ & $\boldsymbol{b}$ & $\boldsymbol{R}^{\mathbf{2}}$ & GT \\
\hline Gonçalves et al. (1997) & SW Portugal coast & 603 & $15.8-35.5$ & 0.0758 & 3.037 & 0.91 & $+\mathrm{A}$ \\
\hline Santos et al. (2002) & South Portugal coast & 90 & $14.2-28.2$ & 0.0085 & 3.040 & 0.967 & $+\mathrm{A}$ \\
\hline Monteiro et al. (2006) & South Portugal coast & 837 & $7.4-30.5$ & 0.079 & 3.01 & 0.979 & $+\mathrm{A}$ \\
\hline Dulčić \& Glamuzina (2006) & Eastern Adriatic Sea & 85 & $9.7-16.7$ & 0.0169 & 2.815 & 0.975 & $-\mathrm{A}$ \\
\hline Torres et al. (2012) & SW Spain & 454 & $8.5-30.9$ & 0.0147 & 2.842 & 0.94 & $-\mathrm{A}$ \\
\hline Bottari et al. (2014) & Tyrrhenian Sea & 2217 & $23.0-33.0$ & 0.023 & 3.118 & 0.995 & $+\mathrm{A}$ \\
\hline Soykan et al. (2015) & Aegean Sea & 421 & $11.0-23.8$ & 0.005 & 3.251 & 0.968 & $+\mathrm{A}$ \\
\hline Present study & Southern Adriatic Sea & 720 & $13.3-29.3$ & 0.0385 & 2.522 & 0.905 & $-\mathrm{A}$ \\
\hline
\end{tabular}

$\left.R^{2}=0.907\right)$, males $\left(W=0.0106 L_{t}^{2.963}, R^{2}=0.884\right)$ and both sexes combined $\left(W=0.0112 L_{t}^{2.911}\right.$, $\left.R^{2}=0.899\right)$. Changes in fish shape, growth increment or break in growth, some of the environmental factors such as temperature and food availability can affect the growth exponent (b) (FROST, 1945). Negative allometry was also recorded in other studies of length-weight relationship in the Adriatic Sea (DULČIĆ \& GLAMUZINA, 2006) and in the study of TORRES et al. (2012) carried out at Gulf of Cadiz (SW Spain). In other studies (GONÇALVES et al., 1997; SANTOS et al., 2002; MONTEIRO et al., 2006; BOTTARI et al., 2014; SOYKAN et al., 2015) growth of bogue showed positive allometry (Table 1).

Values of the condition factor are relatively low for both sexes. Maximum values were recorded in September 1.025 for females and 1.029 for males and minimum in April 0.87 for

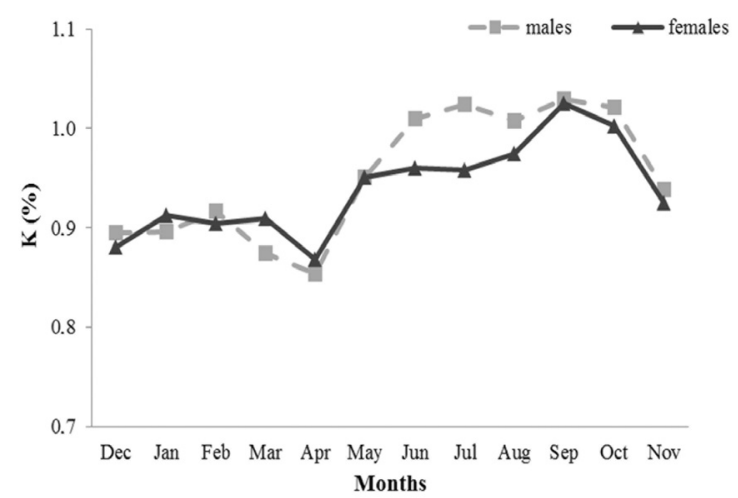

Fig. 2. Monthly values of condition factor (K) for males $(n=311)$ and females $(n=365)$ of bogue, Boops boops in the Adriatic Sea females and 0.85 for males. Monthly variation of condition factor shows a better condition between May and October and decrease of the condition between December and April (Fig. 2). Results from this study showed that values of condition index follow the reproductive cycle with lower values recorded during the spawning period of this species in the Adriatic Sea. The condition factor is a result of the weight-length relationship and it is under direct influence of age, sex, gonad maturity and fullness of the stomach (BARNHAM \& BAXTER, 1998). Condition of the fish is also strongly influenced by biotic environmental condition and can be used to assess the ecosystem status (ANENE, 2005).

Based on monthly obtained GSI values spawning period of this species in the Adriatic Sea extend from January to May. Mean maximum values were recorded in February

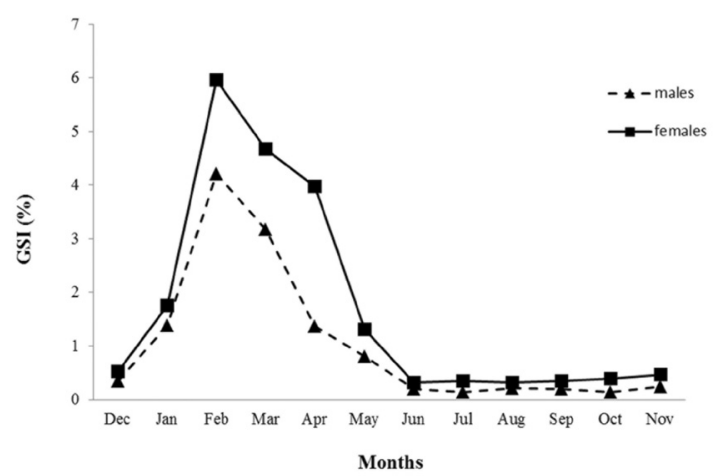

Fig. 3. Monthly gonadosomatic index (GSI) values for males $(n=311)$ and females $(n=365)$ of bogue, Boops boops in the Adriatic Sea 

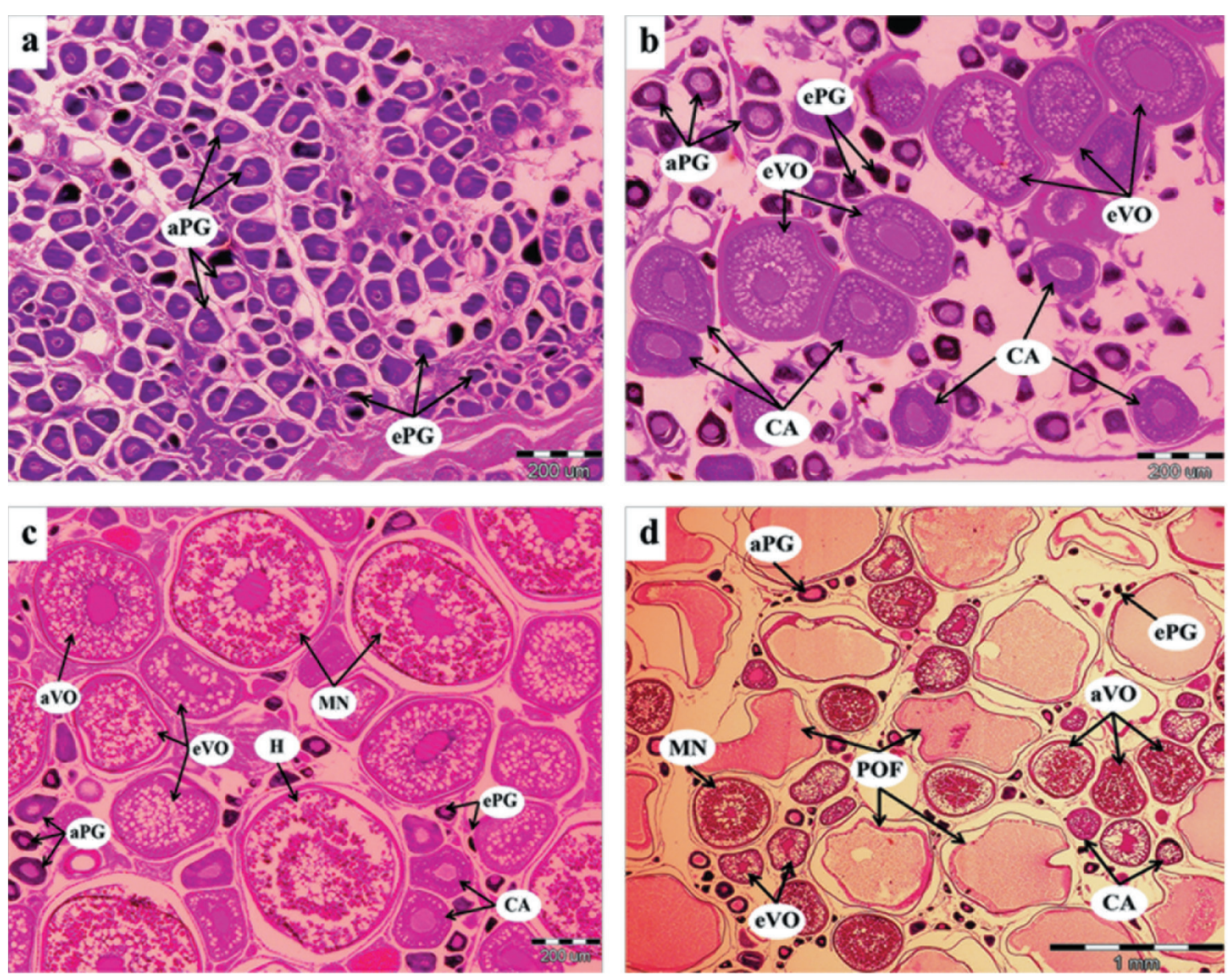

Fig. 4. Histological features of maturity stages of the ovaries of bogue, Boops boops in the Adriatic Sea: $a-i m m a t u r e ; ~ b$ - undergoing maturation; c-spawning; $d$-spent. ePG - early primary growth, aPG-advanced primary growth; $C A$ - cortical alveolar stage; eVO - early vitellogenic stage; aVO - advanced vitellogenic stage; $M N$ - migtatory nucleus stage; $H$ - hydrated oocyte; POF - Post ovulation follicle

for both females (5.97\%) and males (4.21\%) and minimum in June for females (0.32) and July for males $(0.14)$. In the period from June to September minimum values were recorded for both females and males indicating immature and resting phase of gonad development (Fig. 3). SOYKAN et al. (2015) for the Aegean Sea reported similar results, from December to April. BOTTARI et al. (2014) reported a spawning period from January to May with a peak in March for Tyrrhenian Sea. Different spawning period could be related with the differences in ecological parameters of investigated areas, especially temperature.

During August and September oocytes were in primary growth stage and ovaries were composed of oocytes in chromatin nucleolus and perinucleolar stage (Fig. 4a). In males this period is characterized by a big proliferation of spermatogonial cells forming a continuous population of primary and secondary spermatogonia (Fig. 5a). Increased ovarian and testes activity was recorded during November associated with a higher frequency of oocytes in cortical alveoli stage (Fig. 4b) and intensive growth and increase in number of spermatocytes (Fig. 5b). In this period the size of ovaries was enlarged due to deposition of yolk and fat. During winter ovaries were in advanced maturation stage containing vitellogenic oocytes with a clearly visible yolk and oil droplets and nucleus situated in the middle of the oocyte. High number of oocytes with migrating nucleus and hydration was also visible in this period (Fig. 4c). Seminal 

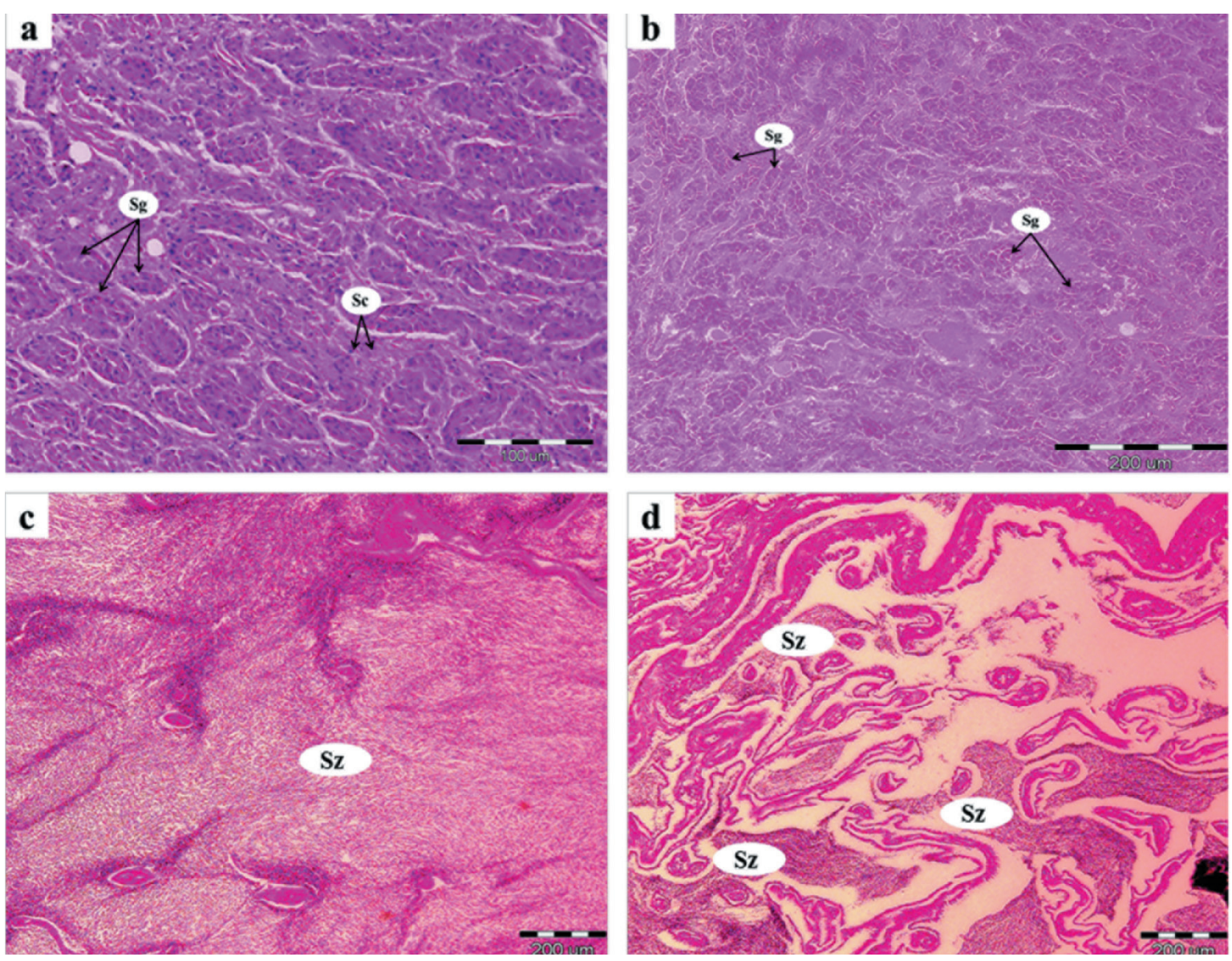

Fig. 5. Histological features of maturity stages of the testes in bogue, Boops boops in the Adriatic Sea: a - immature/ resting; $b$ - undergoing maturation; c-mature/spawning; $d$-spent. Sg-spermatogonia; Sc - spermatocyte; Szspermatozoa

ducts in this period were completely filled with mature spermatozoa (Fig. 5c). Ripe ovaries were found during June and July containing large number of empty nests and unovulated oocytes undergoing resorption (Fig. 4d) and testis were spent with residual spermatozoa spread throughout ducts (Fig. 5d).

Frequency of oocyte diameter follows the changes in gonadosomatic index and results of histological slides analyses. Previtellogenic oocytes with diameter less than $150 \mu \mathrm{m}$ were present in ovaries during the whole year. During the immature stage the mean size of oocyte was in range from $46.9 \mu \mathrm{m}$ (June) to $66.85 \mu \mathrm{m}$ (October). Vitellogenic oocytes start to appear at the end of November and are visible in ovaries until the end of spawning period, during these months diameter increases from 160 to $590 \mu \mathrm{m}$ (Fig. 6).
Total length of females used to determine fecundity ranged from 15.8 to $27.8 \mathrm{~cm}$, total body weight from 34.49 to $103.46 \mathrm{~g}$ and gonad weight from 3.073 to $5.659 \mathrm{~g}$. Values of fecundity ranged from 125802 to 251502 eggs per female. The fecundity of bouge population in

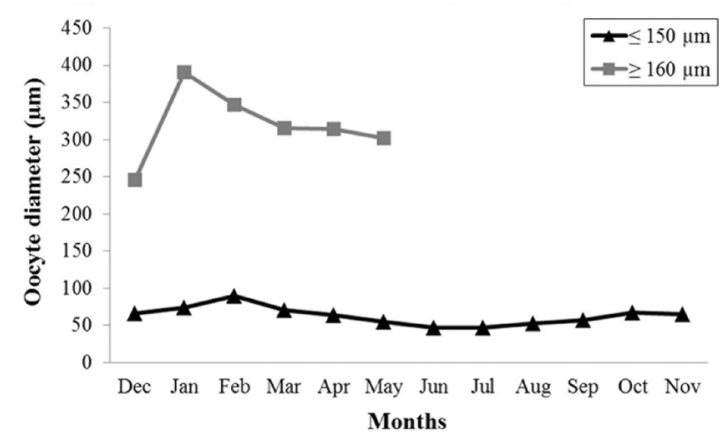

Fig. 6. Monthly average value of oocyte diameter in ovarian of bogue, Boops boops in the Adriatic Sea 
Portuguese waters varied from 11550 to 357 800 per female (GORDO, 1996). The highest recorded value was 395000 eggs, for female with total length $32 \mathrm{~cm}$ (BAUCHOT \& HUREAU, 1986). Compared with the data of other authors, the maximum fecundity in this study was somewhat lower, because of the lack of larger individuals recorded for Adriatic.

Based on the histological sections and oocytes size distribution the ovarian development of the bogue is group-synchronous.

TYLER \& SUMPTER (1996) described two spawning patterns; total and batch spawners. Distribution of the different maturity stages revealed that this species is a batch spawner; clutch of yolked oocytes ovulated during the reproductive season with maximum peak in February while ovaries from June to August were all in immature/resting stages. Aldo this is one of the most abundant species of the family Sparidae high exploitation and low price makes bouge a species with high risk of overexploitation. Knowledge of reproductive biology is vital for rational management of stocks.

\section{REFERENCES}

ANENE, A. 2005. Condition factors of four cichlid species of a man-made lake in Imo state, Southeast, Nigeria. Turk. J. Fish. Aquat. Sci., 5: 43-47.

BAUCHOT, M. L. \& J. C. HUREAU. 1986. Sparidae. In: P.J.P. Whitehead, M.-L. Bauchot, J.-C. Hureau, J. Nielsen and E. Tortonese (Editors) Fishes of the north-eastern Atlantic and the Mediterranean. volume 2. UNESCO, Paris. pp. 883-907.

BOTTARI, T., V. MICALE, M. LIGUORI, P. RINELLI, B. BUSALACCHI, R. BONFIGLIO \& S. RAGONESE. 2014. The reproductive biology of Boops boops (Linnaeus, 1758) (Teleostei: Sparidae) in the southern Tyrrhenian Sea (Central Mediterranean). Cah. Biol. Mar., 55: 281294.

BARNHAM, C. \& A. BAXTER. 1998. Condition Factor, K, for Salmonid Fish. Fisheries Notes. State of Victoria, Department of Primary Industries 2003:3 pp

DOBROSLAVIĆ, T., A. ZLATOVIĆ, V. BARTULOVIĆ, D. LUČIĆ \& B. GLAMUZINA. 2012. Diet overlap of juvenile salema (Sarpa salpa), bogue (Boops boops) and common two-banded sea bream (Diplodus vulgaris) in the southeastern Adriatic. J. Appl. Ichthyol., 29: 1-5.

DULČIĆ, J. \& B. GLAMUZINA. 2006. Length-weight relationships for selected fish species from three eastern Adriatic estuarine systems (Croatia). J. Appl. Ichthyol., 22: 254-256.

EL-AGAMY, A., M.I. ZAKI, G.S. AWAD \& R.K. NEGM. 2004. Reproductive biology of Boops boops
(Family Spariade) in the Mediterranean environment. Egypt. J. Aquat. Res., 30: 241-254.

FROESE, R. 2006. Cube law, condition factor and weight-length relationships: history, metaanalysis and recommendations. J. AppL. Ichthyol., 22: 241-253.

FROST, W.E. 1945. The age and growth of eels (Anguilla anguilla) from the Windermere catchment area. Part 2. J. Anim. Ecol., 14:106-124.

GONÇALVES, J.M.S., L. BENTES, P.G. LINO, J. RIBERIO, A.V.M. CANÁRIO \& K. ERZINI. 1997. Weightlength relationships for selected fish species of the small-scale demersal fisheries of the south and south-west coast of Portugal. Fish. Res., 30: 253-256.

GORDO, L.S. 1995. On the sexual maturity of the bogue (Boops boops) (Teleostei, Sparidae) from Portuguese coast. Sci. Mar., 59: 279286.

GRIER, H.J. 1981. Cellular organization of the testis and spermatogenesis in fish. Am. J. Anat., 159: 331-357.

HUNTER, J.R., B.J. MACEWICZ \& J.R. SIBERT. 1986. The spawning frequency of skipjack tuna, Katsuwonus pelamis, from the south Pacific. Fish. Bull., 84: 895-903.

JARDAS, I. 1996. Jadranska Ihtiofauna. Školska knjiga. Zagreb, pp. 533.

LAEVASTU, T. 1965. Manual of methods in fisheries biology. Section 4. Research of fish stocks. FAO Manual on Fishery Science, 1(9): 1-20. 
LLEONART, J \& F. MAYNOU. 2003. Fish stock assessment in the Mediterranean: state of art. Sci. Mar., 67(1): 37-49.

MONTEIRO, P., L. BENTES, R. COELHO, C. CORREIA, J.M.S. GONCALVES, P.G. LINO, J. RIBEIRO \& K. ERZINI. 2006. Age and growth, mortality, reproduction and relative yield per recruit of the bogue, Boops boops Linné, 1758 (Sparidae), from the Algrave (south of Portugal) longline fishery. J. Appl. Ichthyol., 22: 345352.

MURAYAMA, T., M. SHIRASHI \& I. AOKI. 1994. Changes in ovarian development and plasma levels of sex hormones in the wild female Japanese sardine (Sardinops melanostictus) during the spawning period. J. Fish Biol., 45: 235-245.

MURUA, H \& L. MOTOS. 2006. Reproductive strategy and spawning activity of the European hake Merluccius merluccius (L.) in the Bay of Biscay. J. Fish Biol., 69: 1288-1303.

MURUA, H. \& F. SABORIDO-RAY. 2003. Female Reproductive strategies of Marine Fish Species of the North Atlantic. J. Northw. Atl. Fish. Sci., 33: 23-31.

NELSON, J.S. 2006. Fishes of the World ( $4^{\text {th }}$ Edition). John Wiley \& Sons, Inc. New York, N.Y., pp. 378.
RELINI, G., J. BERTRAND \& A. ZAMBONI. 1999. Synthesis of the knowledge on bottom fishery resources in Central Mediterranean (Italy and Corsica). Biol. Mar. Medit., 6: 382-386.

SANTOS, M.N., M.B. GASPAR, P. VASCONCELOS \& C.C. MONTEIRO. 2002. Weight-length relationships for 50 selected fish species of the Algarve coast (southern Portugal). Fish. Res., 59: 289-295.

SOYKAN, O., A.T. ÍLKYAZ, G. METIN \& H.T. KINACIGIL. 2015. Growth and reproduction of Boops boops, Dentex macrophthalamus, Diplodus vulgaris, and Pagellus acarne (Actinopterygii: Perciformes: Sparidae) from east-central Aegean Sea, Turkey. Acta Ichthyol. Piscat., 45: 39-55.

TORRES, M.A., F. RANOS \& I. SOBRINO. 2012. Length-weight relationship of 76 fish species from the Gulf of Cadiz (SW Spain). Fish. Res., 127-128: 171-175.

TYLER, C.R. \& J.P. SUMPTER. 1996. Oocyte growth and development in teleosts. Rev. Fish. Biol. Fisheries., 6: 287-318.

WEST, G. 1990. Methods of assessing ovarian development in fishes: a review. Aust. J. Mar. Freshwater Res., 41: 199-222.

YELDEN, K. \& S.R. AVSAR. 2000. Fecundities of some fresh water eel. J. Zoo., 10:60-67. 


\title{
Reproduktivne značajke bukve Boops boops (Sparidae) u jugoistočnom Jadranu
}

\author{
Tatjana DOBROSLAVIĆ*, Renata MOZARA, Branko GLAMUZINA i Vlasta BARTULOVIĆ
}

*Kontakt adresa, e-mail: tatjana.dobroslavic@unidu.hr

\begin{abstract}
SAŽETAK
Za potrebe analiziranja reproduktivnih karakteristika bukve, Boops boops u jugoistočnom Jadranu ukupno je prikupljeno i obrađeno 676 jedinki. Uzorci su lovljeni mrežom potegačom u razdoblju od prosinca 2011. do studenog 2012. Ukupna dužina ženki iznosila je od 13,3 do 29,3 cm, a mužjaka od 15,1 do $26,3 \mathrm{~cm}$. Omjer spolova iznosio je 1:0,85 $\left(\chi^{2}=4,314 ; P<0,05\right)$ u korist ženki koje su prevladavale u većim duljinskim razredima. Vrijednosti indeksa kondicije bile su niske kod oba spola, a najveća vrijednost zabilježena je u rujnu 1,025 za ženke i 1,029 za mužjake. Analizom dužinsko-masenog odnosa za cijelu populaciju utvrđena je negativna alometrija $(b=2,911)$. Iz vrijednosti gonadosomatskog indeksa i analiza histoloških preparata gonada zaključeno je da je razdoblje mriješćenja ove vrste u jugoistočnom Jadranu od siječnja do svibnja s vrhuncem u veljači. Ukupno je određeno šest stadija razvoja gonada: nezrele, rani razvoj, dozrijevanje, zreli, mriješćenje i potrošeni. Zastupljenost različitih razvojnih stadija i raspodjela promjera oocita ukazuje na to da se bukva tijekom sezone mrijesti u serijama.
\end{abstract}

Ključne riječi: dužinsko-maseni odnos, oogeneza, spermatogeneza, razmnožavanje, Boops boops 